$\mathrm{Nr} 6$

WARSZAWA-

KRAKÓW 2003

ZBIGNIEW ZIOŁO

Akademia Pedagogiczna, Kraków

\title{
Kształtowanie się przedsiębiorstw przemysłowych w procesie globalizacji
}

Podejmując problematykę kształtowania się przedsiębiorstw przemysłowych w procesie globalizacji wstępnie przyjmujemy, iż każda firma prowadzi działalność gospodarczą czy usługową w celu osiagnnięcia maksymalnego zysku (obecnie lub w dalszym okresie czasu). Do osiagnnięcia tego celu zmierza poprzez rozwijanie działalności gospodarczej, w zależności od zasobów kapitałowych, możliwości produkcyjnych oraz pozycji na rynku (światowym, kontynentalnym, krajowym, regionalnym czy lokalnym), dążąc do coraz lepszego zaspokajania potrzeb i oczekiwań konsumentów. Działaniom tego typu towarzyszą tendencje do stałego podnoszenia produktywności, poprzez wykorzystywanie istniejących zasobów produkcyjnych będących do dyspozycji przedsiębiorstwa.

Problematyka ta nabiera szczególnego znaczenia w obliczu postępującego procesu globalizacji oraz nasilającej się integracji europejskiej. Procesy te wymuszają bowiem na polskich przedsiębiorstwach konieczność dokonywania niekiedy gruntowych zmian związanych z dostosowaniem ich do nowych konkurencyjnych warunków gospodarki światowej głównie poprzez wdrażanie mechanizmów rynkowych (Zioło 1999). Działania te są niezbędne dla zwiększenia konkurencyjności ich produktów czy oferowanych usług ${ }^{*}$. Pozwala to na podnoszenie zdolności ciagłego kreowania wzrostu produktywności, a także skutecznego oferowania nowych, lepszych i tańszych towarów lub usług, aniżeli czynią to inne konkurencyjne firmy (Adamkiewicz 2000). W historycznym procesie wzrostu zmieniała się i nadal zmieniać się będzie funkcja, stopień atrakcyjności określonych układów przestrzennych, a także zestaw instrumentów dla rozwoju już istniejących firm i nowych lokalizacji działalności gospodarczej.

Kształtowanie się przedsiębiorstw przemysłowych w procesie globalizacji dokonuje się więc w bardzo złożonych warunkach. Wynikają one z często odmiennych możliwości, jakie tworzą: poszczególne elementy przestrzeni geograficznej, polityka gospodarcza państwa, jakość ekonomicznych instrumentów pośredniego oddziaływania oraz jakość bezpośrednich instrumentów administracyjno-prawnych. Uwarunkowania te w przestrzeni geograficznej tworzą określony klimat dla prowadzenia działalności gospodarczej, wpływają

* Bardziej szczegółowe rozważania tej problematyki na gruncie nauk ekonomicznych zawierają m.in. prace pod red. R. Borowieckiego (1997, 1998, 1999), A. Stabryły (2000), K. Poznańskiej, A. Sosnowskiej (2002). Wiele empirycznych przykładów zachowań przedsiębiorstw przemysłowych przedstawiono w kolejnych tomach Prac Komisji Geografii Przemysłu PTG (Zioło 2000, 2001, 2002). 
na mechanizmy konkurencji między różnej skali układami przestrzennymi (od skali lokalnej, poprzez regionalna, krajowa, do skali międzynarodowej) oraz określają siłę nabywczą społeczeństwa na dane produkty. Do tych uwarunkowań często w odmienny sposób przystosowują się przedsiębiorstwa przemysłowe w zależności od rozmiarów ich potencjału produkcyjnego, przynależności do odpowiednich gałęzi przemysłu oraz położenia w przestrzeni geograficznej.

\section{MODEL POWIĄZAŃ PRZEDSIĘBIORSTWA PRZEMYSŁOWEGO Z ELEMENTAMI PRZESTRZENI GEOGRAFICZNEJ}

Proces przemian przestrzeni geograficznej stwarza często odmienne warunki dla funkcjonowania i rozwoju różnych typów działalności produkcyjnej czy usługowej, a także kształtuje określone rozmiary chłonności rynków zbytu (Zioło 1997). Oddziaływanie przestrzeni geograficznej na przedsiębiorstwo dokonuje się poprzez relacje pasywne i aktywne (tab. 1). Relacje te możemy rozpatrywać z różnym stopniem szczegółowości. Odnosić się one mogą do przestrzeni geograficznej jako całości, bądź do przestrzeni przyrodniczej, społeczno-gospodarczej czy kulturowej, lub też bardziej precyzyjnie - do poszczególnych elementów przestrzeni geograficznej, np. elementów przyrodniczych $\left[\mathrm{x}_{1}, \ldots, \mathrm{x}_{\mathrm{n}}\right]$, społeczno-

-gospodarczych $\left[\mathrm{y}_{1}, \ldots, \mathrm{y}_{\mathrm{m}}\right]$ czy kulturowych $\left[\mathrm{z}_{1}, \ldots, \mathrm{z}_{\mathrm{k}}\right]$. Poszczególne elementy mogą stwarzać korzystne warunki dla rozwoju przedsiębiorstwa, ograniczać jego działalność do pewnych rozmiarów lub też uniemożliwiać prowadzenie działalności gospodarczej.

Poszczególne elementy w różnym stopniu wpływają na działalność przedsiębiorstwa przemysłowego, np.

- podłoże geologiczne - może dostarczać surowców do produkcji, umożliwiać lokalizację obiektów o różnych współczynnikach nacisku na podłoże, dzięki określonej wytrzymałości gruntu, w połączeniu ze stosunkami wodnymi, może wyznaczać określoną wilgotność i poziom wody gruntowej;

- sieć instytucji finansowych - może tworzyć korzystne warunki otoczenia biznesowego dla rozwoju i lokalizacji działalności produkcyjnej;

- poziom wykształcenia społeczeństwa - umożliwia lokalizację firm o różnym stopniu nowoczesności i zaawansowania technologicznego;

- świadomość społeczna - może tworzyć przyjazny lub nieprzyjazny klimat dla rozwoju działalności i nowych lokalizacji.

Również odwrotnie, przedsiębiorstwo przemysłowe wpływa na poszczególne elementy przestrzeni geograficznej. Może to być oddziaływanie pozytywne (np. zwiększanie rozmiarów zasilania finansowego gospodarstw domowych i ograniczanie bezrobocia, podnoszenie aspiracji i poziomu wykształcenia społeczeństwa, modernizację czy rozwój zagospodarowania infrastrukturalnego) lub destrukcyjne (np. obniżanie jakości ekologicznej środowiska przyrodniczego, eksploatacja i niszczenie zasobów infrastruktury, nadmierna eksploatacja tanich zasobów pracy, obniżanie poziomu i jakości świadomości kulturowej).

Generalnie należy przyjąć, iż w procesie zarządzania konieczne jest rozeznanie jakości poszczególnych elementów przestrzeni geograficznej, występujących w różnej skali układach przestrzennych dla kształtowania na ich obszarze jak najbardziej korzystnych warunków dla rozwoju działalności gospodarczej, a w konsekwencji poprzez te działania 
wpływać na podnoszenie konkurencyjności tych układów dla napływu zewnętrznych czynników rozwoju (np. bezpośrednich inwestycji produkcyjnych czy usługowych). tabela 1 lez 
Z punktu widzenia przestrzeni geograficznej ważnym zagadnieniem jest określanie bilansu działalności przedsiębiorstwa przemysłowego. Dokonać go można określając różnice między wartościami aktywnego wektora oddziaływania przedsiębiorstwa przemysłowego na elementy przestrzeni geograficznej z odpowiednim wektorem oddziaływania pasywnego. Możemy np. porównać różnice między stanem wyjściowym a skutkami działalności przedsiębiorstwa $\mathrm{W}$ zakresie podłoża geologicznego $\left(\mathrm{X}_{1}{ }^{\mathrm{a}}-\mathrm{X}_{1}{ }^{\mathrm{p}}\right)$, zasobów kapitałowych ludności $\left(\mathrm{Y}_{\mathrm{m}}{ }^{\mathrm{a}}-\mathrm{Y}_{\mathrm{m}}{ }^{\mathrm{p}}\right)$ czy w poziomie wykształcenia ludności $\left(\mathrm{Z}_{4}{ }^{\mathrm{a}}-\mathrm{Z}_{4}{ }^{\mathrm{p}}\right)$. Porównania te dają nam istotne przesłanki do podejmowania określonych decyzji co do budowy lub korygowania strategii rozwojowej firmy. Należy przyjąć, iż obecnie nie wszystkie wartości elementów przestrzeni geograficznej potrafimy wyrazić ilościowo, dlatego w niektórych wypadkach trzeba pozostać przy ocenie jakościowej. Należy jednak sądzić, iż w wyniku dalszych badań potrafimy obecnie niemierzalne cechy w przyszłości kwantyfikować.

W historycznym procesie przemian w strukturze przestrzeni geograficznej wykształciły się różnej skali układy przestrzenne, od skali lokalnej, poprzez skalę regionalną, krajową po skalę grupy państw (Zioło 1988). Porównanie wektorów odnoszących się do powiązań pasywnych i aktywnych wyróżnionych kategorii układów przestrzennych pozwala na dokonanie bilansu działalności danego przedsiębiorstwa w danej skali układu przestrzennego (Zioło 1978). W ocenie bilansu mogą wystąpić liczne konflikty, np. ocena bilansu działalności przedsiębiorstwa $z$ pozycji układu krajowego czy regionalnego może być korzystna, natomiast z pozycji układu lokalnego negatywna, lub też odwrotnie. Rozwiązywanie lub łagodzenie konfliktów wymaga więc odpowiednich negocjacji oraz poszukiwania kompromisów między danymi układami przestrzennymi.

\section{MODEL FUNKCJONOWANIA PRZEDSIĘBIORSTWA W OTOCZENIU GOSPODARCZYM}

Przedsiębiorstwo przemysłowe nie jest samodzielnym elementem przestrzeni geograficznej, ale funkcjonuje w określonym otoczeniu. Otoczenie to tworzą inne firmy reprezentujące określone branże przemysłowe, różnej kategorii układy przestrzenne (np. ośrodki czy okręgi przemysłowe lub układy regionalne czy lokalne) czy przemysł krajowy (tab. 2). Jego działalność i kierunki rozwoju stymuluje określona polityka przemysłowa lub szerzej - krajowa polityka gospodarcza, która poprzez określone instrumenty realizuje założone cele ponadnarodowe, krajowe, regionalne czy lokalne. Polityka ta stwarza określone warunki dla kształtowania się otoczenia biznesu oraz szerszego otoczenia krajowego, które stwarza określone ramy zarządzania działalnością firmy.

Uwarunkowania krajowe nie występują samodzielnie, ale związane są z uwarunkowaniami jakie tworzy gospodarka Unii Europejskiej, gospodarka krajów Europy Środkowej, gospodarki wiodących światowych biegunów wzrostu (Stanów Zjednoczonych i Japonii),

a także gospodarki pozostałych obszarów świata. Powszechnie znana jest teza, iż tempo rozwoju gospodarki wiodących światowych biegunów wzrostu jest siłą napędową zarówno gospodarek pozostałych obszarów, jak i poszczególnych przedsiębiorstw. 
Przedstawione w modelu segmenty tworzą więc bardzo złożony system wzajemnych powiązań sieciowych, w których funkcjonuje i rozwija się przedsiębiorstwo przemysłowe (tab. 2).

Tabela 2. Model uwarunkowań funkcjonowania przedsiębiorstwa przemysłowego w otoczeniu

\begin{tabular}{|c|c|c|c|c|c|c|c|c|c|c|c|c|c|c|c|}
\hline \multirow{2}{*}{\multicolumn{3}{|c|}{ Segmenty modelu }} & \multicolumn{13}{|c|}{ Segmenty modelu } \\
\hline & & & \multirow{2}{*}{$\begin{array}{c}\mathrm{E} \\
\mathrm{ee}\end{array}$} & \multirow{2}{*}{$\begin{array}{l}\mathrm{X} \\
\mathrm{ex}\end{array}$} & \multirow{2}{*}{$\begin{array}{c}\text { Y } \\
\text { ey }\end{array}$} & \multirow{2}{*}{$\begin{array}{l}\mathrm{C} \\
\mathrm{ec}\end{array}$} & \multirow{2}{*}{$\begin{array}{c}\mathrm{P} \\
\mathrm{ep}\end{array}$} & \multirow{2}{*}{$\mathrm{G}$} & \multirow{2}{*}{ B } & \multirow{2}{*}{ O } & \multirow{2}{*}{$\mathrm{U}$} & \multirow{2}{*}{$\begin{array}{c}\mathrm{S} \\
\mathrm{es}\end{array}$} & \multirow{2}{*}{$\frac{\mathrm{A}}{\mathrm{ea}}$} & \multirow{2}{*}{$\begin{array}{c}\mathrm{J} \\
\mathrm{ej}\end{array}$} & \multirow{2}{*}{ M } \\
\hline \multicolumn{2}{|c|}{ Przedsiębiorstwo przemysłowe } & $\mathrm{E}$ & & & & & & & & & & & & & \\
\hline \multicolumn{2}{|c|}{ Branże przemysłowe } & $\mathrm{X}$ & $\mathrm{xe}$ & $\mathrm{xx}$ & $x y$ & $\mathrm{xc}$ & $x p$ & $\mathrm{xg}$ & $\mathrm{xb}$ & xo & $\mathrm{xu}$ & $\mathrm{xs}$ & xa & $\mathrm{xj}$ & $\mathrm{xm}$ \\
\hline \multicolumn{2}{|c|}{$\begin{array}{l}\text { Układy przestrzenne } \\
\text { (lokalne, regionalne) }\end{array}$} & $\mathrm{Y}$ & ye & $\mathrm{yx}$ & yy & $\mathrm{yc}$ & yp & yg & $\mathrm{yb}$ & yo & $\mathrm{yu}$ & ys & ya & yj & $\mathrm{ym}$ \\
\hline \multicolumn{2}{|c|}{ Przemysł krajowy } & $\mathrm{C}$ & ce & $\mathrm{cx}$ & cy & $\mathrm{cc}$ & $\mathrm{cp}$ & $\mathrm{cg}$ & $\mathrm{cb}$ & co & $\mathrm{cu}$ & cs & $\mathrm{ca}$ & cj & $\mathrm{cm}$ \\
\hline \multicolumn{2}{|c|}{ Krajowa polityka przemysłowa } & $\mathrm{P}$ & pe & $\mathrm{px}$ & py & $\mathrm{pc}$ & $\mathrm{pp}$ & $\mathrm{pg}$ & $\mathrm{pb}$ & po & $\mathrm{pu}$ & ps & pa & $\mathrm{pj}$ & $\mathrm{pm}$ \\
\hline \multicolumn{2}{|c|}{ Krajowa polityka gospodarcza } & $\mathrm{G}$ & ge & gx & gy & gc & gp & gg & $\mathrm{gb}$ & go & $\mathrm{gu}$ & gs & ga & gj & $\mathrm{gm}$ \\
\hline \multicolumn{2}{|c|}{$\begin{array}{l}\text { Otoczenie biznesowe } \\
\text { przedsiębiorstwa }\end{array}$} & B & be & $\mathrm{bx}$ & by & $\mathrm{bc}$ & bp & bg & $\mathrm{bb}$ & bo & bu & bs & ba & bj & bm \\
\hline \multicolumn{2}{|c|}{ Otoczenie krajowe } & $\mathrm{O}$ & oe & $\mathrm{x}$ & oy & oc & op & og & ob. & oo & ou & os & oa & oj & om \\
\hline \multirow{5}{*}{$\begin{array}{l}\text { Otocze- } \\
\text { nie mię- } \\
\text { dzynaro- } \\
\text { dowe }\end{array}$} & $\begin{array}{l}\text { Gospodarka } \\
\text { Unii Europejskiej }\end{array}$ & $\mathrm{U}$ & ue & ux & uy & uc & up & ug & $\mathrm{ub}$ & uo & $\mathrm{uu}$ & us & ua & uj & um \\
\hline & $\begin{array}{l}\text { Gospodarka } \\
\text { Europy Środkowej }\end{array}$ & $\mathrm{S}$ & se & $\mathrm{sx}$ & sy & $\mathrm{sc}$ & $\mathrm{sp}$ & s.g & $\mathrm{sb}$ & so & su & ss & sa & $\mathrm{sj}$ & $\mathrm{sm}$ \\
\hline & $\begin{array}{l}\text { Gospodarka amerykań- } \\
\text { ska }\end{array}$ & A & ae & ax & ay & ac & ap & ag & $\mathrm{ab}$ & ao & $\mathrm{au}$ & as & aa & aj & am \\
\hline & Gospodarka japońska & $\mathrm{J}$ & je & $\mathrm{jx}$ & jy & jc & jp & jg & $\mathrm{jb}$ & jo & ju & js & ja & $\mathrm{jj}$ & $\mathrm{jm}$ \\
\hline & $\begin{array}{l}\text { Gospodarki pozostałych } \\
\text { obszarów świata }\end{array}$ & M & me & $\mathrm{mx}$ & my & $\mathrm{mc}$ & $\mathrm{mp}$ & $\mathrm{mg}$ & $\mathrm{mb}$ & mo & $\mathrm{mu}$ & $\mathrm{ms}$ & $\mathrm{ma}$ & $\mathrm{mj}$ & $\mathrm{mm}$ \\
\hline
\end{tabular}

Źródło: Opracowanie własne

Zachowanie przedsiębiorstwa (E) w strukturze modelu przedstawia wiersz (wektor) relacji aktywnych [ex, ..., em], który opisuje wpływ przedsiębiorstwa na poszczególne segmenty modelu oraz kolumna (wektor) relacji pasywnych $[\mathrm{xe}, \ldots$, me], która przedstawia wpływ poszczególnych segmentów modelu na przedsiębiorstwo. Wyróżnione relacje mogą stwarzać dla przedsiębiorstwa korzystne warunki współpracy z poszczególnymi segmentami modelu, np. z innymi przedsiębiorstwami różnorodnych branż w zakresie powiązań aktywnych [ex] lub powiązań pasywnych [xe], z przedsiębiorstwami danego układu przestrzennego (formy koncentracji przemysłu czy układu samorządowego) [ey, ye], z otoczeniem biznesowym [ed, de] czy z polityką przemysłową kraju [ep, pe]. Wyróżnione segmenty modelu mogą rozwijać na zasadzie sprzężeń łańcuchowych i zwrotnych wzajemną współprace, ale mogą także stwarzać niekorzystne dla nich uwarunkowania konkurencyjne, np. o rynki zbytu, kwalifikowane kadry, zasoby pracy, kapitały itp.

W punktu widzenia przedsiębiorstwa bardzo ważne są informacje dotyczące reguł funkcjonowania poszczególnych segmentów życia społeczno-gospodarczego. Ilustrują je pola położone wzdłuż przekątnej modelu. Np. relacje zachodzące w przemyśle krajowym przedstawia pole $[\mathrm{cc}]$, relacje $\mathrm{w}$ otoczeniu biznesowym - $[\mathrm{bb}]$, relacje gospodarcze w strukturze Unii Europejskiej - [uu], relacje w gospodarce amerykańskiej - [aa]. Do kształtujących się w ich strukturach mechanizmów przemian powinna nawiązać strategia rozwoju przedsiębiorstwa, w której ciągle należy poszukiwać możliwości włączenia się przedsiębiorstwa w złożony układ logistyczny produkcji, rynków zbytu czy szukać dla siebie nowej niszy rynkowej.

Generalnie można przyjąć, iż otoczenie krajowe przedsiębiorstwa stanowią: 
- inne przedsiębiorstwa, które kształtują warunki: konkurencyjne, komplementarne, bądź funkcjonują i rozwijają się niezależne od danego przedsiębiorstwa,

- otoczenie instytucjonalne, głównie biznesowe, poziom kwalifikacji pracowników instytucji publicznych, mentalność społeczeństwa, tworzącego pozytywny lub negatywny klimat dla rozwoju istniejących i lokalizacji nowych firm,

- jakość instrumentów bezpośredniego i pośredniego oddziaływania (administracyjne, legislacyjne, ulgi, zwolnienia $\mathrm{i}$ in.)

- jakość wyposażenia infrastrukturalnego, jakość zasobów pracy, koszty ich pozyskania oraz kwalifikacje i poziom kultury pracy.

Odmienny wpływ na funkcjonowanie i rozwój przedsiębiorstwa przemysłowego wywierają wyróżnione grupy krajów otoczenia międzynarodowego. Gospodarki krajów ekonomicznie rozwiniętych (Unii Europejskiej, Stanów Zjednoczonych, Japonii), ze względu na ich wysoki poziom konkurencyjności, w stosunkowo małym stopniu mogą być dla niego przedmiotem jego powiązań aktywnych (w zakresie zbytu produktów), natomiast łatwiejsze są relacje pasywne, np. w zakresie powiązań kooperacyjnych. Gospodarki krajów Europy

Środkowej

w wyniku pewnych uprzedzeń politycznych, stosunkowo niewielkich zasobów kapitałowych oraz bariery popytowej ludności, również nie stwarzają dogodnych warunków dla rozwijania współpracy. Natomiast pozostałe kraje (np. państwa afrykańskie), znacznie zapóźnione pod względem rozwoju gospodarczego oraz o nieustabilizowanej scenie politycznej, należą do miejsc o bardzo dużym ryzyku w zakresie rozwijania powiązań ekonomicznych.

Należy jednak nadmienić, iż kraje Europy Środkowej i pozostałe kraje należą do perspektywicznych miejsc lokalizacji działalności gospodarczej i rynków zbytu, stąd na ich terenie należy się liczyć z nasilającą się coraz bardziej walką konkurencyjną, w którą włączać się będą także firmy krajów ekonomicznie rozwiniętych. Te bardzo złożone i różnorodne relacje zarysowane w modelu wymagają dalszego pogłębiania intelektualnego oraz dalszych weryfikacji badań empirycznych, w celu możliwie precyzyjnego poznania zmieniających się uwarunkowań funkcjonowania i rozwoju przedsiębiorstwa przemysłowego w umownie wyróżnionych kategoriach otoczenia międzynarodowego.

W nasilających się procesach globalizacji i zacieśniających się relacjach sieciowych coraz trudniej będzie w najbliższej przyszłości samodzielnie funkcjonować przedsiębiorstwom przemysłowym nawet na rynku lokalnym. Np. zakłady odzieżowe produkujące wyłącznie na potrzeby lokalne czy regionalne obecnie są coraz mniej konkurencyjne i bardzo często przegrywają na tym rynku z podobnymi zakładami z Południowo-Wschodniej Azji. Sytuację tę może dopiero zmienić odpowiednia polityka krajowa, celowo ochraniająca np. rynek krajowy czy lokalny dla miejscowych firm. Zachodzi jednak pytanie, czy sytuacja ta byłaby korzystna dla konsumentów i chronionych przedsiębiorstw? Działania ochronne lokalnych producentów z jednej strony doprowadziłyby do utrwalania się produkcji starych i mało konkurencyjnych produktów, a z drugiej, zwiększałyby koszty utrzymania ludności, która obecnie wobec znacznych trudności na rynku pracy nie dysponuje odpowiednimi zasobami finansowymi.

Wobec globalizacji rynku i tworzenia ponadnarodowych korporacji przemysłowych, kapitałowych czy handlowych szczególnie ważną rolę w procesach rozwojowych przedsiębiorstw odgrywają powiązania międzynarodowe. Mogą one działać jako czynniki pobudzające rozwój działalności produkcyjnej lub stwarzać bariery hamujące ich rozwój. Reprezentują je cztery grupy elementów: polityczne, ekonomiczne, społeczne i kulturowe (tab. 3). W obrębie tych grup występuje wiele cech, które mogą zarówno pobudzać, jak 
i ograniczać rozwój działalności produkcyjnej przedsiębiorstwa. Przy podejmowaniu działań na rzecz kreowania określonych strategii rozwoju należy dokonać precyzyjnych analiz diagnostycznych i na ich podstawie przyjmować określone cele strategiczne oraz dokonywać wyboru odpowiednich metod i środków ich realizacji.

Tabela 3. Bariery hamujące powiązania międzynarodowe przedsiębiorstw

\begin{tabular}{|l|l|}
\hline Polityczne & $\begin{array}{l}\text { Niska jakość stosunków międzypaństwowych } \\
\text { Niedostosowanie instrumentów prawnych } \\
\text { Niestabilność sceny politycznej }\end{array}$ \\
\hline
\end{tabular}

\begin{tabular}{|l|l|}
\hline \multirow{2}{*}{ Ekonomiczne } & $\begin{array}{l}\text { Niekorzystna asymetria rozwoju } \\
\text { Niedobory (nadwyżki) produktów } \\
\text { Niska konkurencyjność produktów } \\
\text { Niska konkurencyjność usług } \\
\text { Niska (wysoka) konkurencyjność zasobów pracy } \\
\text { Ujemny bilans obrotów handlowych } \\
\text { Niska konkurencyjność regionów } \\
\text { System ceł, monopolizacja } \\
\text { Niekorzystny kurs walutowy } \\
\text { Inflacja } \\
\text { Niewielkie zasoby finansowe społeczeństwa }\end{array}$ \\
\hline
\end{tabular}

\begin{tabular}{|l|l|}
$\longrightarrow$ & Społeczne \\
& $\begin{array}{l}\text { Nieprzyjazne stosunki społeczne } \\
\text { Nadwyżki (niedobór) zasobów pracy } \\
\text { Drenaż mózgów }\end{array}$ \\
\hline
\end{tabular}

\begin{tabular}{|c|c|}
\hline Kulturowe & Niska jakość zasobów intelektualnych \\
\hline
\end{tabular}

Czynniki wspomagające powiązania międzynarodowe

\begin{tabular}{|l|l|}
\hline \multirow{2}{*}{ Polityczne } & $\begin{array}{l}\text { Poprawne stosunki międzypaństwowe } \\
\text { Korzystne instrumenty prawne } \\
\text { Stabilność sceny politycznej }\end{array}$ \\
\cline { 2 - 3 }
\end{tabular}

\begin{tabular}{|l|l|}
\hline Ekonomiczne & $\begin{array}{l}\text { Zbliżony poziom rozwoju gospodarczego } \\
\text { Korzystna asymetria rozwoju } \\
\text { Komplementarność gospodarki } \\
\text { Konkurencyjność produktów } \\
\text { Konkurencyjność usług } \\
\text { Konkurencyjność zasobów pracy } \\
\text { Korzystny bilans handlowy } \\
\text { Konkurencyjność regionów }\end{array}$ \\
\hline
\end{tabular}

\begin{tabular}{|l|l|}
\cline { 2 - 3 } Społeczne & $\begin{array}{l}\text { Przyjazne stosunki społeczne } \\
\text { Nadwyżki (niedobór) zasobów pracy } \\
\text { Możliwości wymiany osiagnięć naukowo-badawczych } \\
\text { Znaczące zasoby finansowe ludności }\end{array}$ \\
\hline
\end{tabular}




\begin{tabular}{|l|l|l|}
\hline \multirow{2}{*}{ Kulturowe } & $\begin{array}{l}\text { Wysoka jakość zasobów intelektualnych } \\
\text { Wspólne tradycje kulturowe } \\
\text { Wysoki poziom wykształcenia }\end{array}$ \\
\cline { 2 - 3 } &
\end{tabular}

Źródło: Opracowanie własne

Proces koncentracji kapitału prowadzi do kształtowania się coraz większych korporacji ponadnarodowych, skupiających coraz poważniejsze środki kapitałowe. W wyniku rozwoju w ich strukturze organizacyjnej centrów badań naukowych i wdrażania do produkcji coraz nowocześniejszych artykułów, korporacje te podnoszą swoją konkurencyjność i w konsekwencji wpływają na rozszerzanie przestrzenne i pogłębianie rynków zbytu (tab. 4). Ważną rolę w tym zakresie odgrywają także poszukiwania nowych rynków oraz nowych miejsc lokalizacji działalności gospodarczej.

W układzie przestrzennym korporacje ponadnarodowe poprzez różnorodne powiązania sieciowe rozszerzają swój terytorialny zasięg działania na coraz to nowe obszary. Na zajmowanych obszarach funkcjonują zazwyczaj wcześniej zlokalizowane przedsiębiorstwa, które pozostają poza układami organizacyjnymi korporacji międzynarodowych. Działalność tego typu korporacji zmienia więc dotychczasowe uwarunkowania funkcjonowania istniejących przedsiębiorstw, w wyniku czego podejmują one określone strategie działania wobec pojawiającej się konkurencji. Zachowania firm pozostających poza korporacją mogą przybierać różne formy oraz wykształcać określone rodzaje powiązań, a to:

- może nastąpić włączanie istniejących firm do struktur organizacyjno-kapitałowych korporacji ponadnarodowej w drodze konsolidacji; towarzyszy temu utrzymanie dotychczasowej produkcji oraz włączenie jej w sieci dystrybucyjne do bardziej złożonej korporacji,

- mogą zostać wykupione przez korporacje; wówczas może nastąpić dokapitalizowanie istniejącej firmy, modernizacja procesów produkcyjnych oraz włączenie produkcji do sieci dystrybucyjnej korporacji lub może też nastapić likwidacja firmy jako konkurenta dla produktów danej korporacji; może tu również chodzić tylko o pozyskanie znanej marki na rynku międzynarodowym i wykorzystanie jej dla zbytu swoich wyrobów,

- może nastąpić upadek danej firmy jako mniej konkurencyjnej jednostki, która straciła swoje rynki zbytu na rzecz rozwijającej się korporacji,

- mogą pojawić się nowe firmy współpracujące z korporacją, które powstały pod jej wplywem,

- mogą pojawić się nowe konkurencyjne firmy, które podejmują walkę o rynek (np. firmy samochodowe),

- mogą pojawić się firmy wypełniające pojawiającą się niszę rynkową wywołaną przez korporacje,

- mogą funkcjonować firmy niezależne od korporacji, w małym stopniu powiązane z działalnością produkcyjną, rynkową czy kapitałową.

W trakcie dalszych badań będzie można bardziej precyzyjnie określać typy zachowań firm przemysłowych wobec nasilających się procesów globalizacji, pobudzanych przez ponadnarodowe korporacje.

Jednym z głównych kierunków rozwoju gospodarki światowej jest ekspansja korporacji ponadnarodowych i kapitału zagranicznego, co ma niemałe znaczenie dla krajów słabiej rozwiniętych, w tym także dla Polski. Zapoczątkowane zmiany systemowe mające na celu otwarcie gospodarki polskiej na otoczenie rynku międzynarodowego ułatwiają ten 
proces. W konsekwencji krajowe przedsiębiorstwa przemysłowe funkcjonują w coraz bardziej złożonym otoczeniu, które odznacza się coraz większą konkurencyjnością przy rosnącej barierze popytowej społeczeństwa. Również w przyszłości coraz bardziej nasilać się będzie rywalizacja między przedsiębiorstwami o rynki zbytu dla swoich produktów i źródła zaopatrzenia surowcowego, kredyty, kapitał, energię, o dostęp do infrastruktury techniczno-ekono-micznej i społecznej oraz o dostęp do informacji.

Tabela 4 lez 
Transformacja gospodarki, a w szczególności restrukturyzacja przedsiębiorstw jest ściśle powiązana $\mathrm{z}$ dużymi nakładami finansowymi oraz zmianą systemów zarządzania (Stabryła 2000). Ważną rolę w tym zakresie odgrywają odpowiednio zasobne źródła zasilania kapitałowego, które może tworzyć kapitał państwowy (budżet krajowy), prywatny kapitał rodzimy, własne zasoby finansowe przedsiębiorstw, kapitał zagraniczny, w tym kapitał korporacji międzynarodowych.

Wobec poważnych trudności finansowych budżetu państwa polskiego należy przyjąć, iż wpływ kapitału państwowego na pozytywne działania w zakresie restrukturyzacji przedsiębiorstw będzie ograniczony, zwłaszcza wobec poważnych napięć społecznych (np. w rolnictwie, górnictwie węgla kamiennego, hutnictwie czy przemyśle stoczniowym), których likwidacja wymaga znacznych wydatków ze środków budżetowych. W tych trudnych warunkach ekonomicznych realizowane są często interesy określonych ugrupowań politycznych czy związków zawodowych, zbijających swój kapitał polityczny, przy stosunkowo niskiej świadomości politycznej społeczeństwa. Na niezadowalającą pomoc ze strony państwa w zakresie restrukturyzacji przedsiębiorstw wpływają także, obok stanu finansów publicznych, obiektywne trudności ekonomiczne związane ze zmianami systemu gospodarowania, otwarciem gospodarki na otoczenie międzynarodowe oraz mała dojrzałość sceny politycznej, której przedstawiciele działają bardziej według interesów własnych ugrupowań aniżeli interesu społecznego.

Poprzedni system centralnego sterowania oraz związane $\mathrm{z}$ nim zasady ideologiczne nie dawały możliwości tworzenia rodzimego kapitału prywatnego. Jego rozmiary są więc stosunkowo niewielkie i nie pozwalają na przejęcie i dokapitalizowanie większych firm. Rodzimy kapitał wpływa więc w zasadzie tylko na powstawanie stosunkowo niewielkich firm osób fizycznych, przy czym ich intensywniejszy rozwój ogranicza bariera popytowa ludności oraz brak możliwości kształtowania powiązań kooperacyjnych z dużymi firmami produkcyjno-montażowymi.

Bardzo ograniczone są również własne zasoby kapitałowo-finansowe przedsiębiorstw, które można by przeznaczyć na ich modernizację i podniesienie pozycji konkurencyjnej na rynku. Wdrażane mechanizmy prywatyzacji, które początkowo objęły przedsiębiorstwa najbardziej efektywnie działające na rynku, miały głównie na celu dostarczanie określonych środków finansowych do budżetu krajowego, a nie zasilanie kapitałowe procesów restrukturyzacji. Najmniej efektywne przedsiębiorstwa nie znajdowały nabywcy lub ograniczono w nich proces prywatyzacji ze względów politycznych, np. górnictwo węgla kamiennego czy hutnictwo. Pozostałe w nich silne struktury ruchu związkowego były dla opozycji ważnym czynnikiem nacisku na władzę państwową i w zasadniczym stopniu ograniczały możliwość działań restrukturyzacyjnych (Poznański 2001). Wobec słabości władzy państwowej pojawiły się zjawiska patologiczne, związane np. z wyprowadzaniem środków finansowych $\mathrm{z}$ dobrze prosperujących przedsiębiorstw, co prowadziło do upadłości wielu firm (np. Elektromis), a także z firm w znacznym stopniu dotowanych przez budżet państwa (np. PKP, górnictwo węglowe).

Szczególną rolę w zakresie restrukturyzacji przedsiębiorstw przemysłowych maja więc inwestycje zagraniczne, które na terenie Polski są stosunkowo nowym zjawiskiem, a ich wzmożony rozwój nastąpił w zasadzie w ciągu ostatniego dziesięciolecia. Podstawowymi formami tego kapitału są inwestycje portfelowe oraz bezpośrednie inwestycje zagraniczne. Inwestycje portfelowe to głównie lokaty w papiery wartościowe na terenie innego państwa, np. w obligacje czy akcje. Z kolei inwestycje bezpośrednie polegają na nabyciu przeważającej części udziałów w zagranicznym przedsiębiorstwie, co daje możliwość kon- 
troli nad nim, lub na tworzeniu nowego przedsiębiorstwa od podstaw, tzw. greenfield investments (Olesiński 1998, Bojar 2001). Głównym celem inwestycji zagranicznych jest osiągnięcie zysków w krótkim lub dłuższym okresie czasu. Oznacza to, iż w obecnych uwarunkowaniach rozwoju gospodarczego Polski podstawowym czynnikiem rozwoju gospodarki może być podnoszenie atrakcyjności poszczególnych regionów dla napływu bezpośrednich inwestycji zagranicznych, poszukiwania nowych możliwości powiązań istniejących firm z rynkami międzynarodowymi oraz stwarzanie warunków dla rozwoju rodzimej myśli naukowo-technicznej umożliwiającej kształtowanie centrów wytwarzania nowoczesnych produktów.

Przedstawione rozważania wskazują na dwa zasadnicze problemy funkcjonowania przedsiębiorstwa przemysłowego. Dotyczą one relacji firmy z poszczególnymi elementami środowiska geograficznego oraz ich powiązań rynkowych $\mathrm{z}$ różnej skali układami przestrzennymi. Obecnie funkcjonujące firmy odznaczają się jednak różnymi możliwościami w tym zakresie ze względu na ich różny potencjał gospodarczy, możliwości podejmowania decyzji oraz różny poziom rozwoju społeczno-gospodarczego najbliższego otoczenia. Dlatego relacje zachodzące między nimi wymagają szczególnie precyzyjnej analizy w celu ciagłego doskonalenia strategii rozwoju dla racjonalnego sterowania przedsiębiorstwem przemysłowym, opartych na kryteriach ekonomicznych.

\section{Literatura}

Adamkiewicz H.G., 2000, Produktywność jako czynnik wzrostu konkurencyjności polskich przedsiębiorstw w perspektywie integracji z Uniq Europejska, [w:] Strategie wzrostu produktywności firmy, red. A. Stabryła, Kraków, s. 11-20

Bojar E., 2001, Bezpośrednie inwestycje zagraniczne w obszarach słabo rozwiniętych, Warszawa

Borowiecki R. (red.), 1997, Restrukturyzacja a konkurencyjność przedsiębiorstw, Kraków

Borowiecki R. (red.), 1998, Restrukturyzacja a poprawa efektywności gospodarowania w przedsiębiorstwie, Kraków

Borowiecki R. (red.), 1999, Wyzwania rozwojowe a restrukturyzacja przedsiębiorstw, Kraków

Olesiński Z., 1998, Bezpośrednie inwestycje zagraniczne w Polsce, Warszawa

Poznańska K., Sosnowska A., 2002, Źródta przewagi konkurencyjnej przedsiębiorstw, Warszawa

Poznański K., 2001, Wielki przekręt. Klęska polskich reform, Olsztyn

Stabryła A. (red.), 2000, Strategie wzrostu produktywności firmy, Kraków

Zioło Z., 1978, Powiazania produkcyjno-przestrzenne Tarnobrzeskiego Okręu Przemystowego, „Rocznik Naukowo-Dydaktyczny WSP w Krakowie”, z. 62, Prace Geograficzne VII, Kraków, s. 135-151

Zioło Z., 1988, Funkcjonowanie i rozwój przedsiębiorstwa przemysłowego w przestrzeni geograficznej, [w:] Zakład przemysłowy w akademickim kształceniu nauczycieli geografii, red. Z. Zioło, Kraków, s. 8-24

Zioło Z., 1997, Miejsce struktury przestrzennej przemystu w przestrzeni geograficznej, [w:] Geografia, Człowiek, Gospodarka. Profesorowi Bronisławowi Kortusowi w 70. rocznice urodzin, Kraków, s. 125-132

Zioło Z. (red.), 1999, Europejskie uwarunkowania przemian układów regionalnych, Rzeszów

Zioło Z. (red.), 2000, Problemy transformacji struktur przemystowych w procesie przechodzenia do gospodarki rynkowej, Prace Komisji Geografii Przemysłu PTG nr 1, Warszawa-Kraków

Zioło Z. (red.), 2001, Problemy przemian struktur przemystowych $w$ procesie wdrażania regut gospodarki rynkowej, Prace Komisji Geografii Przemysłu PTG nr 3, Warszawa-KrakówRzeszów 
Zioło Z. (red.), 2002, Problemy transformacji struktur przemystowych, Prace Komisji Geografii Przemysłu PTG nr 4, Warszawa-Kraków-Reszów 